Article

\title{
Insights into Alexandrium minutum Nutrient Acquisition, Metabolism and Saxitoxin Biosynthesis through Comprehensive Transcriptome Survey
}

\author{
Muhamad Afiq Akbar ${ }^{1}$, Nurul Yuziana Mohd Yusof ${ }^{2}{ }^{\oplus}$, Fathul Karim Sahrani ${ }^{2}$, Gires Usup ${ }^{2}$, Asmat Ahmad ${ }^{1}$, \\ Syarul Nataqain Baharum ${ }^{3}\left[\right.$, , Nor Azlan Nor Muhammad ${ }^{3}\left[\right.$ and Hamidun Bunawan ${ }^{3, *}$ (i) \\ 1 Department of Biological Sciences and Biotechnology, Faculty of Science and Technology, \\ Universiti Kebangsaan Malaysia, Bangi 43600, Malaysia; muhdafiq.akbar@gmail.com (M.A.A.); \\ asmat@ukm.edu.my (A.A.) \\ 2 Department of Earth Science and Environment, Faculty of Science and Technology, Universiti Kebangsaan \\ Malaysia, Bangi 43600, Malaysia; yuziana@ukm.edu.my (N.Y.M.Y.); fathul@ukm.edu.my (F.K.S.); \\ gires@ukm.edu.my (G.U.) \\ 3 Institute of System Biology, Universiti Kebangsaan Malaysia, Bangi 43600, Malaysia; \\ nataqain@ukm.edu.my (S.N.B.); norazlannm@ukm.edu.my (N.A.N.M.) \\ * Correspondence: hamidun.bunawan@ukm.edu.my; Tel.: +60-389-214-570
}

\section{check for} updates

Citation: Akbar, M.A.; Yusof, N.Y.M.; Sahrani, F.K.; Usup, G.; Ahmad, A.; Baharum, S.N.; Muhammad, N.A.N.; Bunawan, $\mathrm{H}$. Insights into

Alexandrium minutum Nutrient Acquisition, Metabolism and Saxitoxin Biosynthesis through Comprehensive Transcriptome Survey. Biology 2021, 10, 826. https:// doi.org/10.3390/biology10090826

Academic Editor: John Korstad

Received: 13 July 2021

Accepted: 13 August 2021

Published: 25 August 2021

Publisher's Note: MDPI stays neutral with regard to jurisdictional claims in published maps and institutional affiliations.

Copyright: (c) 2021 by the authors Licensee MDPI, Basel, Switzerland This article is an open access article distributed under the terms and conditions of the Creative Commons Attribution (CC BY) license (https:// creativecommons.org/licenses/by/ $4.0 /)$.
Simple Summary: Alexandrium minutum is one of the causing organisms for the occurrence of harmful algae bloom (HABs) in marine ecosystems. This species produces saxitoxin, one of the deadliest neurotoxins which can cause human mortality. However, molecular information such as genes and proteins catalog on this species is still lacking. Therefore, this study has successfully characterized several new molecular mechanisms regarding $A$. minutum environmental adaptation and saxitoxin biosynthesis. Ultimately, this study provides a valuable resource for facilitating future dinoflagellates' molecular response to environmental changes.

Abstract: The toxin-producing dinoflagellate Alexandrium minutum is responsible for the outbreaks of harmful algae bloom (HABs). It is a widely distributed species and is responsible for producing paralytic shellfish poisoning toxins. However, the information associated with the environmental adaptation pathway and toxin biosynthesis in this species is still lacking. Therefore, this study focuses on the functional characterization of $A$. minutum unigenes obtained from transcriptome sequencing using the Illumina Hiseq 4000 sequencing platform. A total of 58,802 (47.05\%) unigenes were successfully annotated using public databases such as NCBI-Nr, UniprotKB, EggNOG, KEGG, InterPRO and Gene Ontology (GO). This study has successfully identified key features that enable A. minutum to adapt to the marine environment, including several carbon metabolic pathways, assimilation of various sources of nitrogen and phosphorus. A. minutum was found to encode homologues for several proteins involved in saxitoxin biosynthesis, including the first three proteins in the pathway of saxitoxin biosynthesis, namely sxtA, sxtG and sxtB. The comprehensive transcriptome analysis presented in this study represents a valuable resource for understanding the dinoflagellates molecular metabolic model regarding nutrient acquisition and biosynthesis of saxitoxin.

Keywords: Alexandrium minutum; dinoflagellates; harmful algae blooms; saxitoxin; transcriptomics

\section{Introduction}

Dinoflagellates have a large genome size of up to $245 \mathrm{Gbp}$ and over 100 chromosomes [1]. This represents one to 80 times the size of the human haploid genome. The size of the dinoflagellate genome also differs from many other eukaryotic algae, whose genome size is usually between tens to hundreds of $\mathrm{Mbp}$ [2]. This unique feature and unusual genome size is a significant barrier to large-scale genomic studies of these organisms [3,4]. To date, the only dinoflagellate genome that has been successfully sequenced is 
limited Symbiodinium spp., Amphidinium gibbosum, Amoebophrya ceratii and Polarella glacialis due to the smallest size genome among dinoflagellates [5-9]. The first draft genome of Symbiodinium minutum has been successfully sequenced by Shoguchi et al. [10] using the Roche 454 GS-FLX platform and Illumina Genome Analyzer IIx (GAIIx) next-generation sequencers, which assembled a total of $616 \mathrm{Mpb}$ of genome out of a total of $1.5 \mathrm{Gpb}$ of total genome size predicted for the species. However, dinoflagellates of the genus Symbiodinium are dinoflagellates in symbiosis with corals and do not produce saxitoxin or trigger the phenomenon of harmful algae blooms (HABs) [11]. Thus, the mechanisms for dinoflagellate toxin biosynthesis, life cycle regulation and response to environmental changes at the molecular level remain poorly understood due to the lack of genome and gene information involved in the process [1,3].

A transcriptomic approach using a next-generation sequencing platform, such as Illumina Hiseq, is an alternative for studying organisms with complex genomes such as dinoflagellates [12]. The transcriptomic approach is an ideal and holistic approach to analyze the mRNA sequences expressed by cells at specific times and conditions. There are existing transcriptomic data of several dinoflagellate species contributing to the phenomenon of HABs including both toxic (Alexandrium minutum, Alexandrium fundyense, Alexandrium catenella, Prorocentrum minimum and Karenia brevis) and non-toxic (Alexandrium tamutum, Prorocentrum donghaiense, Scrippsiella trochoidea, Cochlodinium polykrikoides, Amphidinium carterae, Prorocentrum micans) strains have been reported using transcriptomic approach via next-generation sequencing platform [3,13-20]. These studies have allowed the discovery of dinoflagellates' response toward stressors and determining putative genes responsible for toxin biosynthesis.

In this study, the next-generation sequencing platform Illumina Hiseq 4000 was used to generate transcriptome data of $A$. minutum. To obtain transcriptome sequence data relevant to the study questions involving the effects of nutrient changes, sequence data were generated from $A$. minutum cultured in normal environment, nitrogen-deficient environment and phosphorus-deficient environment. Several major components in the cellular metabolism of A. minutum, as well as homologues for the saxitoxin biosynthesis gene will be characterized. This study also additional insights into the gene catalog encoded by $A$. minutum along with detailed annotations. The information generated from this study is an important component to understand the mechanism of response to environmental changes as well as the biosynthesis of saxitoxin for A. minutum.

\section{Materials and Methods}

\subsection{Cell Culturing and Harvesting}

The dinoflagellate culture of A. minutum AmKB01 used throughout this study was obtained from the culture collection of the Marine Microbiology and Biotechnology Laboratory, National University of Malaysia. This strain was isolated from the mangrove waters in Tumpat, Kelantan, in 2001 when an outbreak of shellfish poisoning in the area caused one death, and several people were hospitalized. The production of saxitoxin by this strain has been determined by previous studies [21]. The growth medium for A. minutum used in this study was ES-DK media added to seawater with a salinity of $15 \mathrm{psu}$ [22]. The cultures were maintained at $26{ }^{\circ} \mathrm{C}$ at 12:12 h dark: light regime with an irradiance of $100 \mu \mathrm{mol}$ photons $\mathrm{m}^{-2} \mathrm{~s}^{-1}$ light intensity. To include genes expressed under different physiological conditions, A. minutum cells were subjected to nitrogen and phosphorus limitation for $72 \mathrm{~h}$ before harvesting. In order to induce nitrogen/phosphorus limitation, A. minutum cells were cultured in standard ES-DK media first until they reached the exponential phase before being transferred to new ES-DK media without nitrogen/phosphorus component using a $15 \mu \mathrm{m}$ mesh sieve. The absence of nitrogen/phosphorus in the culture media was confirmed using a HACH DR2800 spectrophotometer (HACH, Ames, IA, USA) [23]. 


\subsection{RNA Extraction}

Harvested A. minutum cells were frozen immediately in liquid nitrogen and stored at $-80{ }^{\circ} \mathrm{C}$ until RNA extraction. RNA extraction was performed using Trizol reagent (SigmaAldrich, St. Louis, MO, USA) as per the manufacturer's protocol. The concentration and purity of the extracted RNA were determined using a Nanodrop-1000 Spectrophotometer machine (Thermo Fischer Scientific, Waltham, MA, USA) through readings at $260 \mathrm{~nm}$ and $280 \mathrm{~nm}$ absorption. An absorption reading ratio of 260:280 nm around 1.8 to 2.0 was considered good. Finally, RNA integrity was also measured using a 2100 Bioanalyzer machine (Agilent Technologies, Santa Clara, CA, USA). Intact RNA would show a RIN score above 7. Only RNA samples that show the quality meets the standards would be used for RNA sequencing. Two biological replicates from each treatment group were used for sequencing.

\section{3. cDNA Library Construction and Illumina Sequencing}

According to the manufacturer's protocol, the cDNA library preparation was conducted using SureSelect Strand-Specific RNA Library Prep (Agilent Technologies, Santa Clara, CA, USA). The sequencing of cDNA libraries was performed using the Illumina Hiseq4000 150PE (Theragen Etex, Suwon, Gyeonggi, Korea) platform.

\subsection{Transcriptome Assembly}

Raw data reads for all samples generated from Illumina sequencing were pre-processed using the Trimmomatic (v0.36) [24]. Next, high-quality raw data reads were assembled de novo via Trinity (v2.8) [25]. The Trinity program was run with modifications on the following parameters namely min_kmer_cov $=2$ and SS_lib_type $=$ RF. The expression level of each transcript assembled was calculated using the RSEM [26]. Transcripts that show an expression level of less than 1 FPKM are considered artifacts and are then discarded using the "filter_low_expr_transcripts.pl" script from the Trinity package. After that, the script from the Trinity package "get_longest_isoform_seq_per_trinity_gene.pl" was used to extract the longest representative for each transcript that will be called unigenes. These unigenes were then used in further analysis throughout this study.

\subsection{Quality Evaluation of Transcriptome Assemblies}

This study used two methods to evaluate the quality of the A. minutum assembled unigenes: assessing the percentage of raw data mapping to the transcriptome assemblies and based on the conserved orthologue sequence content [27]. The HISAT2, a fast and sensitive alignment program for mapping sequence reads to transcriptome data sets, is used to evaluate the percentage of raw data re-mapping [28]. Next, the presence of preserved orthologous sequence content was assessed using the BUSCO based on the Eukaryotic data set (odb9) [29]. In addition, the "contig_ExN50_statistic.pl" script from the Trinity package was used to compute the ExN50 profile of our assembled unigenes.

\subsection{Prediction of the Protein-Coding Sequence}

Protein-encoding sequences were identified from A. minutum unigenes using the TransDecoder program [25]. Uniprot and Pfam-A databases were used to maximize the accuracy of the ORF sequence identification.

\subsection{Transcriptome Annotation}

The unigenes sequences were annotated against protein databases, NCBI non-redundant protein (NCBI-Nr) and UniprotKB (SwissProt and TrEMBL) using the blastx program with e-value parameter $\leq 0.00001$ [30]. Next, the InterProScan 5 was used to predict the domain for the identified ORF of A. minutum. The program identified homologies for protein domains compiled from 15 databases (Phobius, TMHMM, Pfam, ProDom, Gene3d, Panther, SuperFamily, Coils, SMART, PrositeProfiles, PRINTS, SignalP, PIRSF, TIGRFAMs and HAMAP) [31]. The classification of ORF sequences A. minutum to ortholog protein groups 
was carried out using EggNOG 5.0 [32]. Finally, the annotation of A. minutum unigenes to the biochemical pathway from the Kyoto Encyclopedia of Genes and Genomes (KEGG) database was performed using the GhostKoala program [33]. Subcellular localization of proteins was predicted bioinformatically through the BUSCA webserver [34].

The Blast2GO 5.2 program was used to define gene ontology (GO) terms for each unigenes in the A. minutum transcriptome set [35]. The GO term is filtered using the parameter "permissive annotation" to remove the incorrectly matched GO term. To determine additional GO terms for unigenes in this study, the Blast2GO 5.2 program was also used to combine GO terms from the InterPRO and EggNOG matching results to the existing GO terms. Figure 1 displays the flow chart for the transcriptome analysis method in this study.

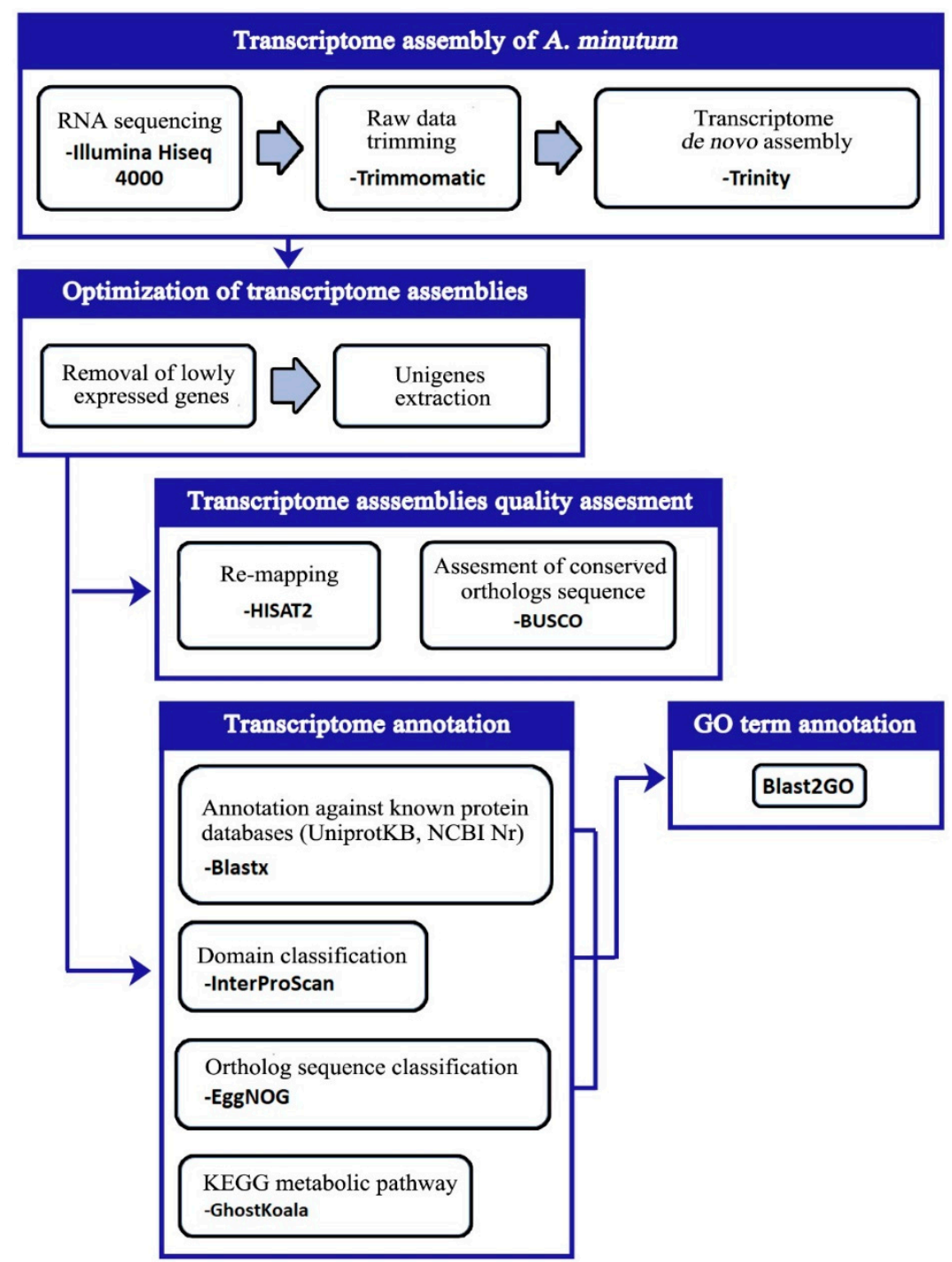

Figure 1. Flow chart of $A$. minutum transcriptome analysis method used in this study.

\subsection{Identification of Putative Saxitoxin Genes}

With reference to the pathway of saxitoxin biosynthesis by Kellman et al. [36], saxitoxin biosynthesis protein sequences from cyanobacteria were downloaded from the NCBI Nr database as FASTA format. Next, the "makeblastdb" function of the Blast+ program was used to generate a protein database consisting of cyanobacterial saxitoxin biosynthesis proteins [30]. Finally, the blastx program was used to match the A. minutum unigene sequence to a newly constructed cyanobacterial saxitoxin biosynthesis protein database with a parameter value of $\mathrm{e} \leq 0.00001$. 


\section{Results and Discussions}

\subsection{Transcriptome Sequencing and De Novo Assembly}

The A. minutum transcriptome cDNA library was generated from six biological samples induced by three different environments (control, nitrogen deficiency, and phosphorus deficiency) using Illumina Hiseq 4000 platform sequencing platform. A total of 295.4 million high-quality readings with base readings of $40.63 \mathrm{Gpb}$ were successfully produced (Supplementary Material Table S1). Next, de novo assembly using Trinity and filtering of the transcript with an expression value below 1 FPKM produced a total of 124,977 final unigenes for A. minutum to be used in downstream analysis. The unigenes produced comprised $112.07 \mathrm{Mbp}$, had a value of N50 at $1566 \mathrm{bp}$ and the average unigenes length was at $896.69 \mathrm{bp}$ (Table 1). Moreover, almost $50 \%$ of the assembled unigenes have lengths exceeding $500 \mathrm{bp}$.

Table 1. Statistical summary of $A$. minutum unigenes generated using de novo assembly approach.

\begin{tabular}{cc}
\hline Statistic & Unigenes \\
\hline Total unigenes & 124,977 \\
GC\% & 6430 \\
N50 (bp) & 1566 \\
Unigenes median lenght (bp) & 468 \\
Unigenes mean lenght (bp) & 89,669 \\
Total base pairs & $112,065,669$ \\
BUSCO score & $83.5 \%$ \\
\hline
\end{tabular}

To date, there is still no gold standard method for determining the quality of transcriptome assemblies for non-model organisms such as dinoflagellates. This study takes the approach suggested by Tong et al. [27]. To evaluate the quality of the A. minutum unigenes, the raw reads were mapped back to the assembled unigenes using HISAT2, and the results showed that $80 \%$ of the total reads were mapped correctly. The completeness of A. minutum unigenes was assessed based on the ortholog content maintained through the BUSCO based on the Eukaryotic data set (odb9) [29]. As a result, 83.5\% of the 303 BUSCO orthologues ( $71.0 \%$ complete; $12.5 \%$ fragmented) were identified from $A$. minutum unigenes. In addition, the ExN50 profile of our assembled unigenes peaked at 91\% of the total expression indicating an adequate sequencing depth (Supplementary Material Table S2) [37].

\subsection{Coding Region Prediction}

The TransDecoder was used to predict ORF sequences and protein sequence translation from the assembled unigenes. UniProtKB and Pfam databases were used to help identify ORFs. A total of 67,093 unigenes ( $53.68 \%$ of the total unigenes) were predicted to encode ORFs with an average value of 419 amino acids and an N50 value of 536 amino acids. Among the predicted ORFs, a total of 44,376 ORFs contained start codons and end codons, indicating that these ORFs were present as ORFs with a complete sequence. ORF sequences were used to perform annotation against KEGG, EggNOG and InterPro databases.

\subsection{Unigenes Annotation}

To determine the function of the assembled unigenes, all unigenes were compared to the sequences available in public databases such as the NCBI Nr, UniProtKB, KEGG, InterPro, EggNOG and GO databases. Of the 124,977 unigenes compared against the NCBI Nr database, only $58,802(47.05 \%)$ unigenes produced significant matches, while the InterPro database annotation results recorded a total of 57,605 (46.09\%) significant matches (Table 2). A total of $70 \%$ (27,552 unigenes) of the unigenes annotation results against the NCBI Nr database showed homology with proteins from dinoflagellate Symbiodinium microadriaticum (Figure 2A). Other matches with the NCBI Nr database were also included proteins from other marine phytoplankton groups, such as Vitrella brassicaformi (1927 unigenes), Emiliania huxleyi (846 unigenes), Perkinsus marinus (827 unigenes), Fragilariopsis cylindrus 
(544 unigenes) and Chrysochromulina sp. (489 unigenes). Protein similarity distribution shows that $47.5 \%$ of unigenes sequences had similarities higher than $60 \%$, and $52.5 \%$ of unigenes sequences showed similarity between $33 \%$ and $60 \%$ to known protein (Figure 2B). According to the distribution of expected e values from the top matches based on the NCBI $\mathrm{Nr}$ database, $40 \%$ of the matched unigenes sequences showed high homology $\left(<1 \times 10^{-45}\right)$, while $60 \%$ of the matched sequences showed moderate homology (between $1 \times 10^{-5}$ and $1 \times 10^{-45}$ ) (Figure 2C). Overall, these results indicate that $A$. minutum assembled unigenes maintains a level of conservation with known proteins.

Table 2. A minutum unigenes annotation results against different databases.

\begin{tabular}{cc}
\hline Databases & Annotated Unigenes \\
\hline NCBI-Nr & $58,802(47.05 \%)$ \\
UniProtKB & $58,495(46.80 \%)$ \\
EggNOG & $34,602(27.69 \%)$ \\
KEGG & $18,381(14.70 \%)$ \\
InterPro & $57,605(46.09 \%)$ \\
Gene Ontology (GO) & $57,128(45.71 \%)$ \\
\hline
\end{tabular}

More than $50 \%$ of the assembled unigenes did not show any match with any of the protein sequences found in the NCBI Nr and UniprotKB databases. The low annotation success rate is primarily due to the very limited number of dinoflagellate reference genomes. To date, available dinoflagellate genome data consists only of symbiotic or parasitic species except for $A$. gibbosum [6-8,10,11,38-40]. This group was selected for sequencing because of its small genome size, i.e., $0.12-6.4 \mathrm{Gbp}[5,8,9]$. In comparison, other dinoflagellate genomes are much larger, ranging between $3-245 \mathrm{Gbp}$ [13]. Thus, the matching of dinoflagellate transcriptome data to protein databases such as NCBI Nr and UniprotKB is seen to be highly dependent on sequence sources from other phytoplankton groups. Despite having a low match to the protein sequences found in the NCBI Nr database, the annotation results of our A. minutum transcriptomes showed a comparable percentage of annotations than some other recent studies of other dinoflagellate transcriptomes such as A. minutum (42.3\%), Amphidinium carterae (33\%), Prorocentrum donghaiense (40\%), Scrippsiella trochoidea $(41 \%)$, Yihiella yeosuensis (47.7\%), Gambierdiscus polynesiensis (51.8\%) and Gambierdiscus pacificus (51.1\%) [15,41-45].

Annotated unigenes from NCBI Nr, UniprotKB, EggNOG and Interpro were further assigned to GO terms. A total of 57,128 unigenes were successfully assigned into 17,563 GO terms. For the biological process category, the three main GO terms are "organic substance metabolic process" (GO: 0071704; 22,264 unigenes), "cellular metabolic process" (GO: 0044237; 21,450 unigenes) and "primary metabolic process" (GO: 0044238; 21,365 unigenes). Furthermore, the category of molecular function is dominated by the terms GO "organic cyclic compound binding" (GO: 0097159; 15,150 unigenes), "heterocyclic compound binding" (GO: 1901363; 15,113 unigenes) and "ion binding" (GO: 0043167; 14,913 unigenes). Finally, the category of cellular components is represented by the terms GO "organelle" (GO: 0043226; 17,239 unigenes), "intracellular organelle" (GO: 0043229; 17,075 unigenes) and "cytoplasm" (GO: 0005737; 15,500 unigenes) (Figure 3). Full annotation for A. minutum transcriptome are available in Supplementary Material Table S3. 

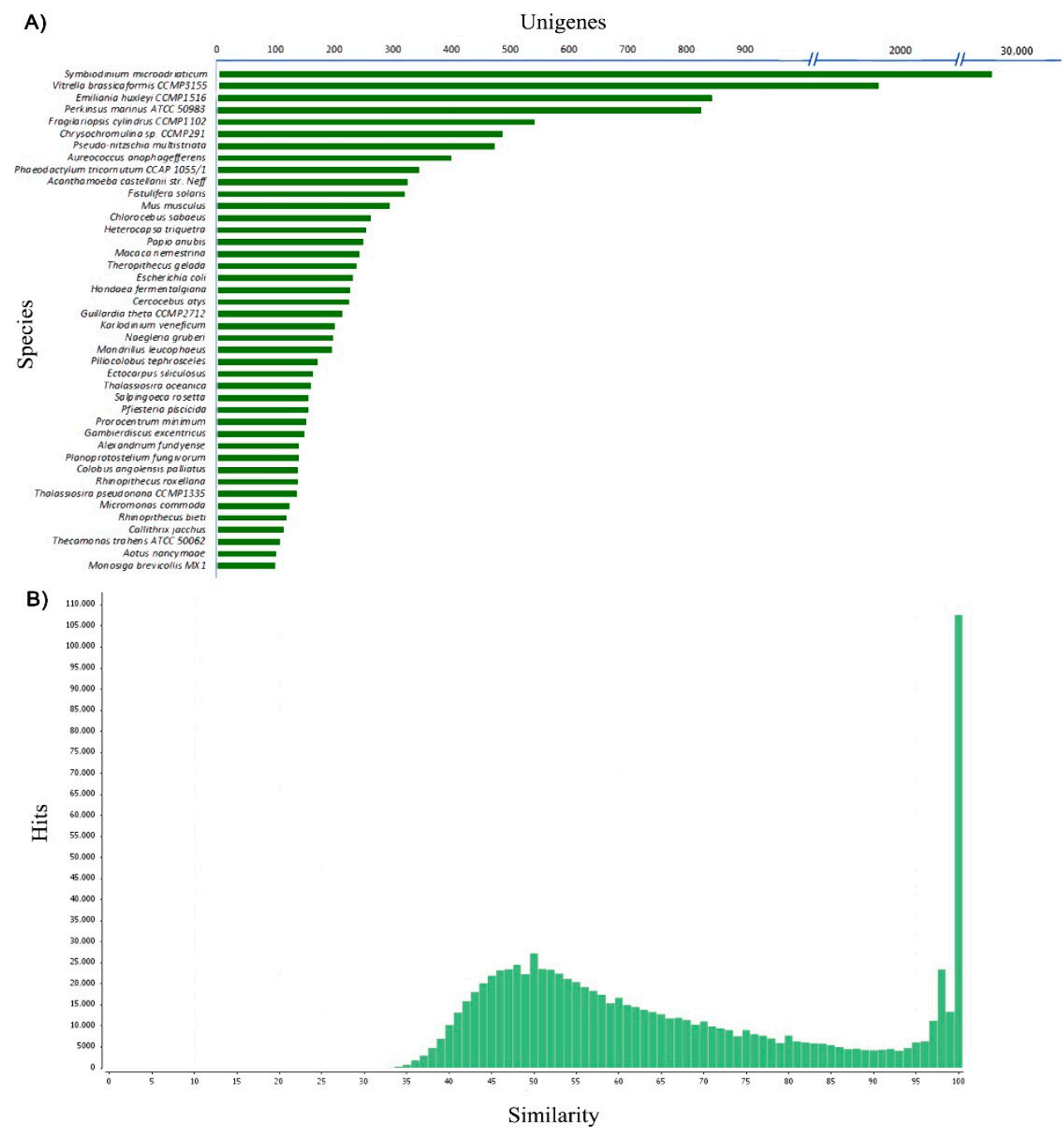

C)

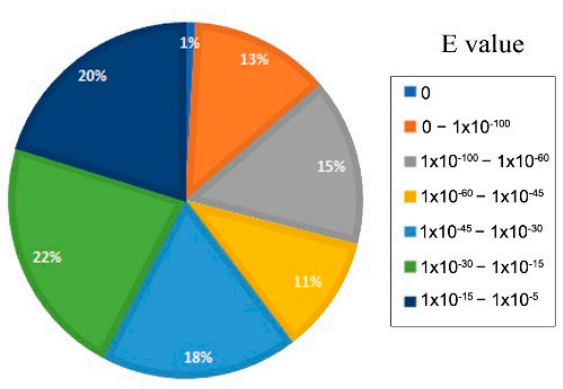

Figure 2. Annotation of A. minutum unigenes against the NCBI-NR database. (A) The homological species distribution for A. minutum. (B) The percentage of similarity of sequences identified using blastx program and (C) the distribution of $\mathrm{E}$ values of the blastx hit. 


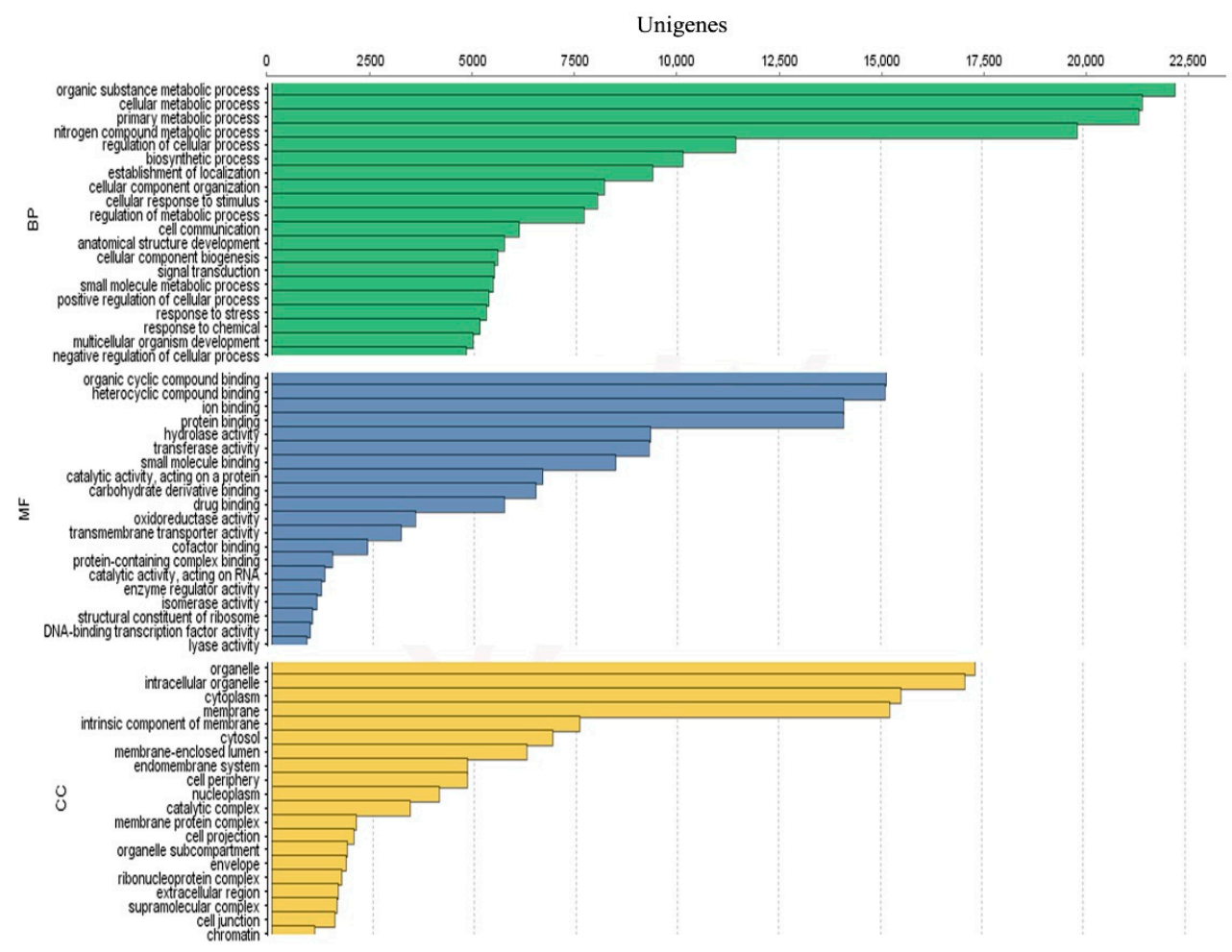

Figure 3. Annotation of GO terms from categories of cellular components (CC), molecular function (MF) and biological processes (BP) for A. minutum unigenes. Only the top 20 terms for each category are shown.

\subsection{Carbon Metabolism}

Carbon degradation is a source of energy metabolism and biosynthetic processes for most organisms [46]. A. minutum obtains its carbon source from carbon dioxide and/or organic compounds. Complete genes for core metabolic pathway sites such as Kelvin cycle, tricarboxylic acid cycle (TCA), Embden-Meyerhof-Parnas pathway (EMP or glycolysis) and pentose phosphate pathway (PP) were identified in the A. minutum transcriptome (Figure 4). Both EMP and PP pathways are often seen as the backbone of carbon and energy metabolism for eukaryotic organisms, including in phytoplankton such as diatoms [47,48]. These metabolic pathways play an essential role in generating ATP, NAD (P) H and precursors for biosynthetic amino acids, nucleotides, and fatty acids [46].

The diffusion of $\mathrm{CO}_{2}$ in the moving marine environment is 5000 times slower than the atmosphere and indirectly limits the uptake of carbon sources by phytoplankton such as dinoflagellates [49]. Thus, in contrast to terrestrial plants that rely on the RubisCO protein as the protein responsible for the carbon fixation process, some phytoplankton such as Phaeodactylum tricornutum, Thalassiosira pseudonana, Ostreococcus tauri and Micromonas sp. have developed $C 4$ carbon fixation pathway [50-54]. Based on the transcriptome analysis in this study, A. minutum encode complete genes required for the $\mathrm{C} 4$ carbon fixation pathway. A study by Gong et al. [55] also found that genes encoding proteins in the C4 carbon fixation pathway site in dinoflagellates showed increased expression levels during the occurrence of HABs, indicating that this pathway may play an important role during HABs.

Apart from identifying all the enzymes required for the expression of the EMP pathway site, which is the most common glycolytic pathway site present in all organisms, the transcriptome analysis of $A$. minutum in this study also successfully identified the homologues gene-encoding phosphoketolase, the enzyme involved in C5 sugar reduction to produce acetyl phosphate in PP pathway [56]. Homologues for this gene in the marine phytoplankton organism have only been identified in the diatom P. tricornutum [57].

Moreover, homologues for almost all proteins involved in the Entner-Doudoroff pathway were also identified in the transcriptome of A. minutum (except phosphogluconate dehydratase). The Entner-Doudoroff pathway serves as an alternative metabolic pathway 
to the EMP pathway for the degradation of glucose molecules to pyruvate. This pathway produces lower energy per glucose than EMP pathways but has advantages in terms of lower protein costs and thermodynamic energy [58]. Previously, the Entner-Doudoroff pathway was considered limited to prokaryotic organisms until the discovery of this pathway in diatom P. tricornutum by Fabris et al. [57]. Recent studies have also shown a wider distribution of the Entner-Doudoroff pathway, with genomic evidence supporting the presence of these pathways on cyanobacteria, ferns, algae, mosses and plants [46].

Based on transcriptome analysis, A. minutum can utilize carbon sources from several metabolic pathways such as EMP, PP, phosphoketolase and Entner-Doudoroff pathways. Several past studies have demonstrated that activation of the different metabolic pathways can produce differences at phenotypic levels, such as activation of virulence factors in some bacteria $[59,60]$. Since biosynthesis saxitoxin in dinoflagellates also depends on precursors, such as arginine and acetyl-CoA from carbon metabolism, the association between carbon metabolic pathways and saxitoxin biosynthesis is an essential niche of study.

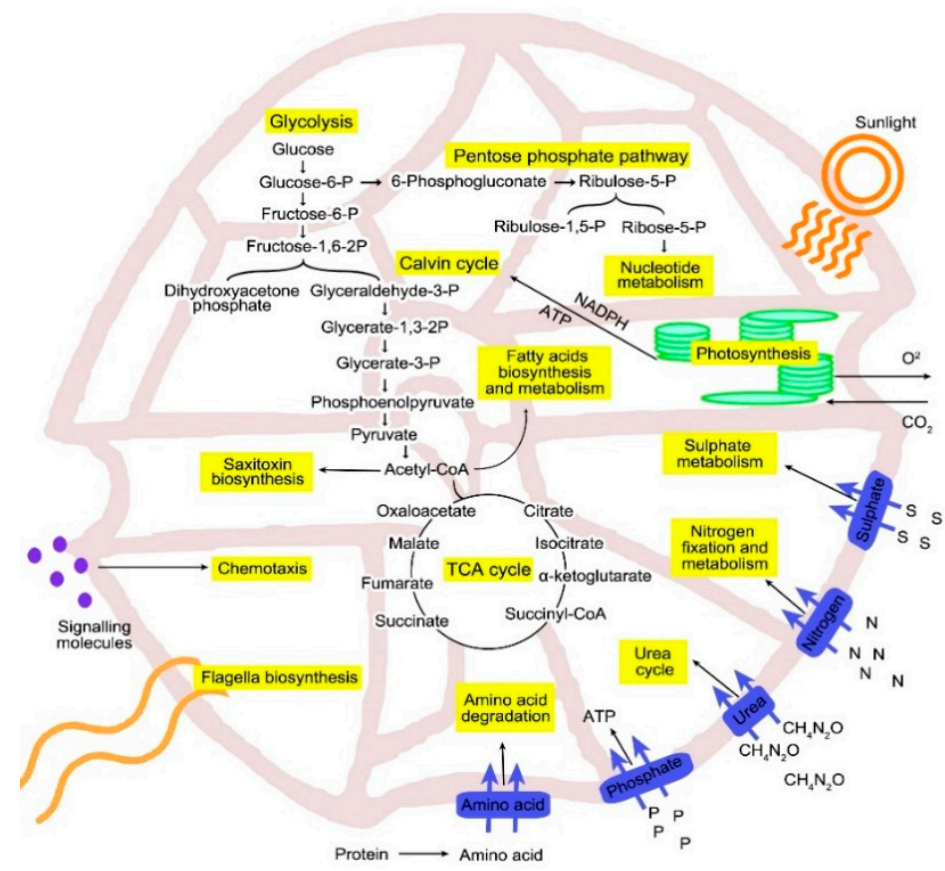

Figure 4. A metabolic pathway model of carbohydrate metabolism and related processes for A. minutum.

\subsection{Nitrogen Metabolism}

The overall configuration and function of the nitrogen metabolic network for dinoflagellates, including A. minutum still receives less attention compared to other model organisms. To assess this more closely, a catalog of genes with potential roles in the assimilation and metabolism of nitrate, urea and ammonia was compiled from the unigenes of $A$. minutum. Subcellular localization of proteins was predicted bioinformatically and used to generate an updated model of nitrogen metabolism in A. minutum (Figure 5). Nitrogen metabolism in dinoflagellates is an important branch of study because high nitrogen concentrations often correlate with the phenomenon of HABs and increased rates of saxitoxin production [61-63].

Four homologue types of nitrogen transport proteins (nitrate, nitrite, ammonia and urea) were successfully identified in this study. These results are in agreement with several previous studies proving that dinoflagellates of the genus Alexandrium are indeed capable of taking up nitrogen from this source into cells $[64,65]$. Several recent studies have shown that genes encoding nitrate transporting proteins in Prorocentrum donghaiense and Prorocentrum minimum were regulated at the transcriptional level and regulated with the changes of nitrogen in the environment [66,67]. Nevertheless, a study by Bellefeuille 
and Morse [68] found that nitrate transporting proteins in Lingulodinium polyedrum were continuously expressed with the presence of nitrogen. Expression of urea transport genes also shows regulation at the transcriptional level and correlates to the presence of urea in the environment [66]. However, there are no detailed studies at the molecular level regarding nitrite uptake by dinoflagellates from the marine environment, although this study successfully demonstrated the presence of gene-encoding nitrite transport proteins by $A$. minutum. This is due to the presence of nitrite in the marine environment that is always at a lower concentration compared to other nitrogen sources [69].

Analysis of the subcellular localization of genes encoding proteins related to nitrogen metabolism showed that the process of nitrate reduction to nitrite and subsequently ammonia occurs in the cytoplasm, mitochondria and even chloroplasts (Figure 5). The GS-GOGAT pathway was predicted to be active in all three of these cell compartments and is responsible for assimilating nitrogen sources that have been reduced to ammonia using the proteins glutamine synthetase (GS) and glutamate synthase (GOGAT). This pathway combines glutamine (Gln) to 2-oxoglutarate using 2 electrons of either Fd-reduction or NADP $(\mathrm{H})$ and produces two molecules of glutamate $(\mathrm{Gln})$ and can regenerate Gln when amino acids and 2-oxoglutarate are needed [70]. Both Glu and Gln are essential components for amino acid metabolism and cellular nitrogen regulation because these molecules act as both nitrogen recipients and donors [71]. This study demonstrated that $A$. minutum encodes a homologue gene for glutamate dehydrogenase (GDH) protein, which may be advantageous for A. minutum because ammonia assimilation through the GDH pathway does not require an ATP such as the GS-GOGAT pathway [71].

Our analysis also showed that $A$. minutum encodes all the genes required in the urea cycle pathway site (CPS, carbamoyl phosphate synthase; OTC, ornithine carbamoyltransferase; AsuS, argininosuccinate synthase; AsL, argininosuccinate lyase; Arg, argininosuccinate lyase). The urea cycle pathway site was previously said to be exclusive to metazoan and was not found in green plants and algae until Armbrust et al. [51] found a complete gene for this pathway from the diatom T. pseudonana. However, unlike metazoan organisms that use these pathways to convert highly toxic ammonia into urea for excretory processes, diatoms are seen using these pathways as a method to redistribute carbon and nitrogen to TCA and GS-GOGAT pathways [72]. Since A. minutum also encodes complete proteins for the TCA and GS-GOGAT pathways, the function of the urea cycle pathways in these dinoflagellates may resemble those of diatoms. In addition to A. minutum, homologues for genes involved in the urea cycle pathway site have also been reported in the dinoflagellates of A. tamarense, Gambierdiscus caribaeus and P. donghaiense $[70,73,74]$ 


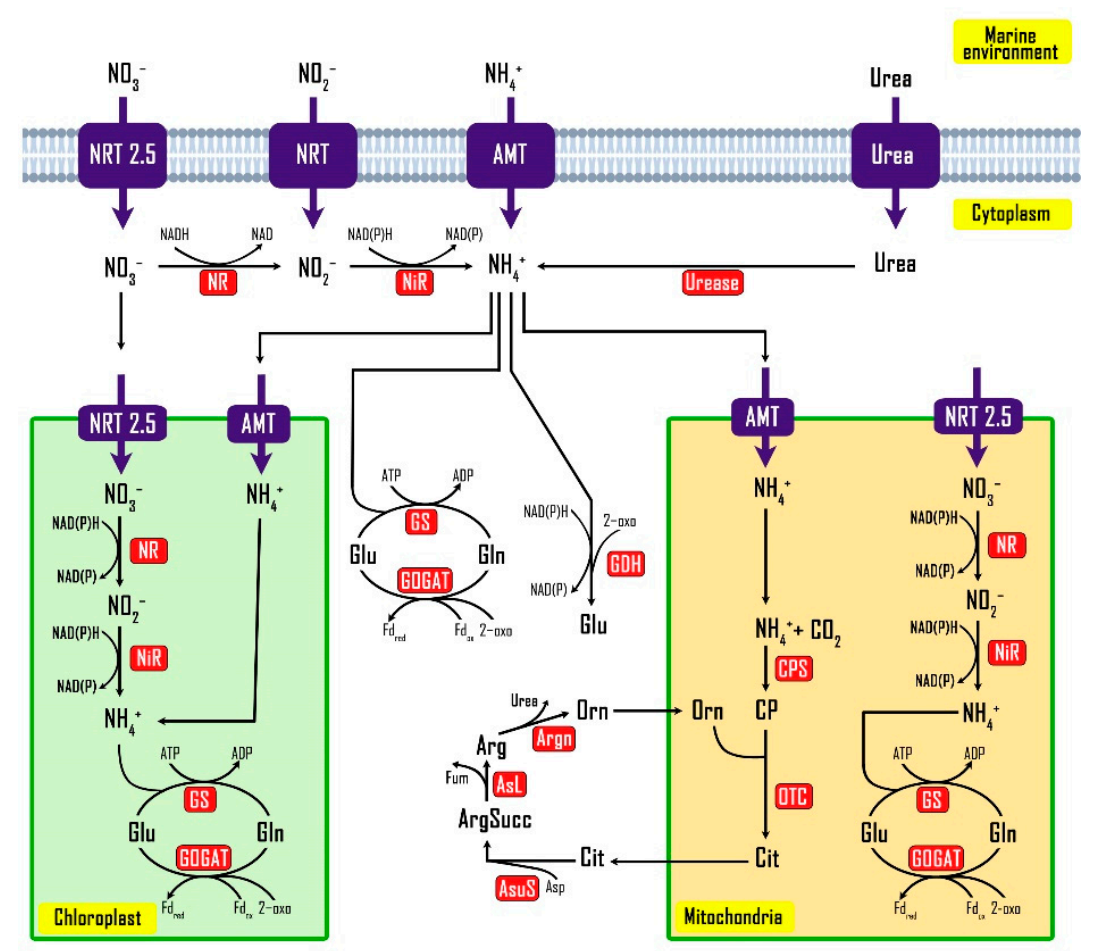

Figure 5. A model for the subcellular localization and metabolic pathway of nitrogen metabolisms by A. minutum. The full names of the proteins within the figure legend are available in (Supplementary Material Table S4).

\subsection{Phosphorus Metabolism}

The uptake of inorganic phosphorus sources from the marine environment by phytoplankton organisms such as dinoflagellates is controlled by phosphorus transport proteins on the cell surface [75]. Several homologue genes for phosphorus transport proteins were identified in this study, such as inorganic phosphate transporter from protozoa Perkinsus marinus and Symbiodinium microadriaticum, low-affinity phosphate transporter from S. microadriaticum and PitA phosphate transporter from Escherichia coli. However, all homologues of the phosphorus transport proteins identified were low-affinity phosphorus transport proteins. To date, the distribution of high-affinity phosphorus transporting proteins has been observed to be limited in eukaryotic phytoplankton organisms [75]. Lin et al. [75] did not rule out the possibility that eukaryotic phytoplankton organisms, including dinoflagellates, have novel high-affinity phosphorus transport proteins. Given that approximately $50 \%$ of the $A$. minutum unigenes has no match with the protein sequence in the public databases, the likelihood that $A$. minutum encoding a novel high-affinity phosphorus transport protein cannot be ruled out.

After the entry of inorganic phosphorus into dinoflagellate cells, this phosphorus will react with adenosine diphosphate (ADP) to produce ATP with the help of ATP synthase protein [76]. Several homologues for this protein were also identified in A. minutum, and through further analysis, the protein was placed in three cell compartments, namely chloroplasts, mitochondria and transmembrane. These results were also in agreement with Lin et al. [75], where ATP is the major product of photosynthesis in chloroplasts, a respiratory product in mitochondria and synthesized by the protein rhodopsin in transmembrane. The resulting ATP will then be used in the metabolic pathways in need.

Phytoplankton, including dinoflagellates, can store excess intracellular phosphorus to support cell metabolism and growth as polyphosphates [75,77]. Five homologues for gene encoding the vacuolar transporter chaperone (VTC) protein were identified on the $A$. minutum transcriptome. VTC is a protein responsible for cutting the phosphorus groups from ATP and transferring them into polyphosphate chains [78]. In addition, A. minutum 
also encodes a PPX-like protein that serves to hydrolyze polyphosphate terminal residues to re-release inorganic phosphorus for the use of metabolic pathways in need [75,78].

\subsection{Saxitoxin Biosynthesis}

Through a blastx search with an E value $<0.00001$ against a database of saxitoxin biosynthesis proteins obtained from cyanobacteria protein sequence, a total of 216 homologues for this protein were identified in the transcriptome sequence A. minutum (Supplementary Material Table S5). These putative proteins include core proteins that are directly involved in the biosynthesis of saxitoxin (sxtA, sxtB, sxtD, sxtG, sxtH/T, sxtI, sxtJ, sxtS, $\mathrm{sxtU}, \mathrm{sxtV}$ and sxtW), four proteins proposed to be involved in the modification of saxitoxin into related derivatives (sxtL, sxtN, sxtO and sxtX) and proteins for saxitoxin transport (sxtF/M and sxtP). Of these proteins, sxtJ was first identified in dinoflagellates [13]. The results of the sxt protein search on A. minutum are shown in Table 3. Our study indicates that $A$. minutum does not encode two of the saxitoxin biosynthesis core proteins (sxtC and sxtK). In fact, to date, no homologue for these proteins has been successfully identified in dinoflagellates [13]. In cyanobacteria, both of these genes encode hypothetical proteins and are predicted to play a regulatory role in the process of saxitoxin biosynthesis [36]. Additionally, homologue for sxtE, sxtQ, sxtR, sxtY and sxtZ proteins were also not identified in this study. Though homologues for sxtR have been identified in A. minutum and $A$. fundyense by Stüken et al. [79], homologues for sxtZ have been identified in $A$. minutum by Meng et al. [15]. The variability of sxt genes even among $A$. minutum strains itself might be due to various toxin profiles exhibit among $A$. minutum strains across their biogeographical distributions [16].

Table 3. The identification of the A. minutum unigenes encoding homologues for proteins involved in the biosynthesis of cyanobacterial saxitoxins using the blastx with an E value $<0.00001$.

\begin{tabular}{|c|c|c|c|}
\hline Categories & Genes & Putative Function & Unigenes \\
\hline \multirow[t]{13}{*}{ Core genes } & sxtA & $\begin{array}{l}\text { Methylation, loading of } \mathrm{ACP}, \\
\text { Claisen condensation }\end{array}$ & 14 \\
\hline & sxtB & Cyclization & 1 \\
\hline & $\operatorname{sxtC}$ & Regulatory & - \\
\hline & sxtD & Desaturation & 1 \\
\hline & sxtG & Amidinotransfer & 4 \\
\hline & $\mathrm{sxtH} / \mathrm{T}$ & C-12 hydroxylation & 21 \\
\hline & sxtI & Carbamoylation & 5 \\
\hline & sxtJ & Regulatory & 1 \\
\hline & sxtK & Regulatory & - \\
\hline & sxtS & Ring formation & 8 \\
\hline & sxtU & Short-chain alcohol dehydrogenase & 131 \\
\hline & sxtV & Dioxygenase reductase & 2 \\
\hline & sxtW & Ferredoxin & 10 \\
\hline \multirow[t]{4}{*}{ Modification genes } & sxtL & Decarbamoylation & 1 \\
\hline & sxtN & Sulfotransferase & 1 \\
\hline & sxtO & PAPS biosynthesis & 9 \\
\hline & $\operatorname{sxt} X$ & $N-1$ hydroxylation & 3 \\
\hline \multirow[t]{2}{*}{ Regulatory genes } & sxtY & Signal transduction & - \\
\hline & sxtZ & Signal transduction & - \\
\hline \multirow[t]{2}{*}{ Transporter genes } & $\mathrm{sxtF} / \mathrm{M}$ & Export of PSTs & 4 \\
\hline & sxtP & Binding of PSTs & 2 \\
\hline \multirow[t]{3}{*}{ Unknown } & sxtE & Unknown & - \\
\hline & sxtQ & Unknown & - \\
\hline & $\operatorname{sxt} \hat{R}$ & Unknown & - \\
\hline
\end{tabular}

Next, the absence of homologues for some sxt proteins in dinoflagellates, including A. minutum, might be due to the biosynthesis process of saxitoxin evolving separately in 
dinoflagellates and cyanobacteria [80]. Thus, saxitoxin biosynthesis proteins from cyanobacteria that do not have any homologues in A. minutum or other dinoflagellates are likely to have been replaced by other protein-encoding proteins with similar biochemical activity. A study conducted by Hackett et al. [81] also stated that only proteins involved in the first three steps in the biosynthesis of saxitoxins (sxtA, sxtG and sxtB) from dinoflagellates have phylogenetic relationships with proteins from cyanobacteria, further reinforcing the claim that saxitoxin biosynthesis in dinoflagellates evolved separately and partially with other proteins. Moreover, the results of the study also indicate that most of the putative saxitoxin biosynthetic proteins identified in this study are present with more than one unigenes or isoform. This is likely due to the homologue for sxt genes in A. minutum is also involved with other biological processes [82]. Therefore, more in-depth studies are needed to study the actual function of the putative proteins of saxitoxin biosynthesis in dinoflagellates, including A. minutum.

\section{Conclusions}

In this study, A. minutum transcriptome profile was successfully generated using Illumina Hiseq 4000 platform. The quality and completeness of our assembled unigenes also were carefully evaluated. Extensive annotation against available databases identifies some important unigenes involved in the process of metabolism of carbon, nitrogen and phosphorus for dinoflagellates. In addition, the existence of phosphoketolase and the Entner-Doudoroff pathway in dinoflagellates were discussed for the first time here. Further work on these pathways activities will enable researchers to understand the complex metabolism of carbohydrates for dinoflagellates. Our results also provide insight into saxitoxin biosynthesis of $A$. minutum. The variability of saxitoxin biosynthesis genes among A. minutum strains might give rise to different toxin profiles. Although our study managed to identify almost all the saxitoxin biosynthesis "core" genes, a more comprehensive study is needed as most of these genes exist with more than one homologue. To the best of our knowledge, the transcriptome profile of $A$. minutum presented here may be the most comprehensive described with regards to major nutrient acquisition and metabolism. The findings reported here will lay a good foundation for understanding the dynamic growth of dinoflagellates during HAB.

Supplementary Materials: The following are available online at https://www.mdpi.com/article/ 10.3390/biology10090826/s1, Table S1: Quality control and filtering of transcriptome raw reads of A. minutum, Table S2: ExN50 profile of A. minutum assembled unigenes, Table S3: Annotation of $A$. minutum transcriptome, Table S4: A. minutum nitrogen metabolism gene catalogue, Table S5: Blastx result of $A$. minutum unigenes against cyanobacterial saxitoxin biosynthesis genes.

Author Contributions: M.A.A. performed the experiment and drafted the manuscript. F.K.S., S.N.B., N.A.N.M. and H.B. contributed analysis tools. N.Y.M.Y., F.K.S., A.A., G.U. and H.B. edited and added valuable insights to the manuscript. All authors have read and agreed to the published version of the manuscript.

Funding: This research was funded by the Malaysia Ministry of Education under the research grant FRGS/1/2019/STG05/UKM/02/6.

Institutional Review Board Statement: Not applicable.

Informed Consent Statement: Not applicable.

Data Availability Statement: Not applicable.

Acknowledgments: The authors would like to acknowledge the Ministry of Higher Education of Malaysia for the financial support.

Conflicts of Interest: The authors declare no conflict of interest. 


\section{References}

1. Lin, S. Genomic understanding of dinoflagellates. Res. Microbiol. 2011, 162, 551-569. [CrossRef]

2. Hou, Y.; Lin, S. Distinct gene number-genome size relationships for eukaryotes and non-eukaryotes: Gene content estimation for dinoflagellate genomes. PLoS ONE 2009, 4, e6978. [CrossRef]

3. Akbar, M.A.; Ahmad, A.; Usup, G.; Bunawan, H. Current knowledge and recent advances in marine dinoflagellate transcriptomic research. J. Mar. Sci. Eng. 2018, 6, 13. [CrossRef]

4. Akbar, M.A.; Ahmad, A.; Usup, G.; Bunawan, H. RNA-seq as an emerging tool for marine dinoflagellate transcriptome analysis: Process and challenges. Processes 2018, 6, 5. [CrossRef]

5. LaJeunesse, T.C.; Lambert, G.; Andersen, R.A.; Coffroth, M.A.; Galbraith, D.W. Symbiodinium (Pyrrhophyta) genome sizes (DNA Content) are smallest among dinoflagellates. J. Phycol. 2005, 41, 880-886. [CrossRef]

6. Yu, L.; Li, T.; Li, L.; Lin, X.; Li, H.; Liu, C.; Guo, C.; Lin, S. SAGER: A database of Symbiodiniaceae and Algal Genomic Resource. Database 2020, 2020, baaa051. [CrossRef]

7. Stephens, T.G.; González-Pech, R.A.; Cheng, Y.; Mohamed, A.; Burt, D.W.; Bhattacharya, D.; Ragan, M.A.; Chan, C.X. Genomes of the dinoflagellate Polarella glacialis encode tandemly repeated single-exon genes with adaptive functions. BMC Biol. 2020, 18, 1-21. [CrossRef]

8. Beedessee, G.; Kubota, T.; Arimoto, A.; Nishitsuji, K.; Waller, R.F.; Hisata, K.; Yamasaki, S.; Satoh, N.; Kobayashi, J.; Shoguchi, E. Integrated omics unveil the secondary metabolic landscape of a basal dinoflagellate. BMC Biol. 2020, 18, 1-16. [CrossRef]

9. John, U.; Lu, Y.; Wohlrab, S.; Groth, M.; Janouškovec, J.; Kohli, G.S.; Glöckner, G. An aerobic eukaryotic parasite with functional mitochondria that likely lacks a mitochondrial genome. Sci. Adv. 2019, 5, eaav1110. [CrossRef]

10. Shoguchi, E.; Shinzato, C.; Kawashima, T.; Gyoja, F.; Mungpakdee, S.; Koyanagi, R.; Hamada, M. Draft assembly of the Symbiodinium minutum nuclear genome reveals dinoflagellate gene structure. Curr. Biol. 2013, 23, 1399-1408. [CrossRef]

11. Liu, H.; Stephens, T.G.; González-Pech, R.A.; Beltran, V.H.; Lapeyre, B.; Bongaerts, P.; Chan, C.X. Symbiodinium genomes reveal adaptive evolution of functions related to coral-dinoflagellate symbiosis. Commun. Biol. 2018, 1, 1-11. [CrossRef]

12. Stark, R.; Grzelak, M.; Hadfield, J. RNA sequencing: The teenage years. Nat. Rev. Genet. 2019, 20, 631-656. [CrossRef]

13. Akbar, M.A.; Yusuf, N.Y.M.; Tahir, N.I.; Ahmad, A.; Usup, G.; Sahrani, F.K.; Bunawan, H. Biosynthesis of saxitoxin in marine dinoflagellates: An omics perspective. Mar. Drugs 2020, 18, 103. [CrossRef] [PubMed]

14. Le Gac, M.; Metegnier, G.; Chomérat, N.; Malestroit, P.; Quéré, J.; Bouchez, O.; Chapelle, A. Evolutionary processes and cellular functions underlying divergence in Alexandrium minutum. Mol. Ecol. 2016, 25, 5129-5143. [CrossRef] [PubMed]

15. Meng, F.Q.; Song, J.T.; Zhou, J.; Cai, Z.H. Transcriptomic profile and sexual reproduction-relevant genes of Alexandrium minutum in response to nutritional deficiency. Front. Microbiol. 2019, 10, 2629. [CrossRef] [PubMed]

16. Geffroy, S.; Lechat, M.M.; Le Gac, M.; Rovillon, G.A.; Marie, D.; Bigeard, E.; Caruana, A. From the sxtA4 gene to saxitoxin production: What controls the variability among Alexandrium minutum and Alexandrium pacificum Strains? Front. Microbiol. 2021, 12, 341. [CrossRef] [PubMed]

17. Wang, H.; Kim, H.; Ki, J.S. Transcriptome survey, molecular identification, and expression analysis of stress-responsive genes in the toxic dinoflagellate Alexandrium pacificum under algicidal agents and metal stresses. J. Appl. Phycol. 2021, 33, 1-13.

18. Vingiani, G.M.; Štālberga, D.; De Luca, P.; Ianora, A.; De Luca, D.; Lauritano, C. De novo transcriptome of the non-saxitoxin producing Alexandrium tamutum reveals new insights on harmful dinoflagellates. Mar. Drugs 2020, 18, 386. [CrossRef]

19. Wang, H.; Kim, H.; Ki, J.S. Transcriptome survey and toxin measurements reveal evolutionary modification and loss of saxitoxin biosynthesis genes in the dinoflagellates Amphidinium carterae and Prorocentrum micans. Ecotoxicol. Environ. Saf. 2020, 195, 110474. [CrossRef]

20. Zhang, Y.; Zhang, S.F.; Lin, L.; Wang, D.Z. Comparative transcriptome analysis of a toxin-producing dinoflagellate Alexandrium catenella and its non-toxic mutant. Mar. Drugs 2014, 12, 5698-5718. [CrossRef]

21. Lim, P.T.; Leaw, C.P.; Usup, G. Harmful algal blooms in Malaysian waters. Sains Malays. 2012, 41, $1509-1515$.

22. Kokinos, J.P.; Anderson, D.M. Morphological development of resting cysts in cultures of the marine dinoflagellate Lingulodinium polyedrum (= L. machaerophorum). Palynology 1995, 19, 143-166. [CrossRef]

23. Mohd-Din, M.; Abdul-Wahab, M.F.; Mohamad, S.E.; Jamaluddin, H.; Shahir, S.; Ibrahim, Z.; Lim, P.T. Prolonged high biomass diatom blooms induced formation of hypoxic-anoxic zones in the inner part of Johor Strait. Environ. Sci. Pollut. Res. Int. 2020, 27, 42948-42959. [CrossRef]

24. Bolger, A.M.; Lohse, M.; Usadel, B. Trimmomatic: A flexible trimmer for Illumina sequence data. Bioinformatics 2014, 30, 2114-2120. [CrossRef]

25. Haas, B.J.; Papanicolaou, A.; Yassour, M.; Grabherr, M.; Blood, P.D.; Bowden, J.; MacManes, M.D. De novo transcript sequence reconstruction from RNA-seq using the Trinity platform for reference generation and analysis. Nat. Protoc. 2013, 8, 1494-1512. [CrossRef]

26. Li, B.; Dewey, C.N. RSEM: Accurate transcript quantification from RNA-Seq data with or without a reference genome. BMC Bioinform. 2011, 12, 1-16. [CrossRef]

27. Tong, G.X.; Xu, W.; Zhang, Y.Q.; Zhang, Q.Y.; Yin, J.S.; Kuang, Y.Y. De novo assembly and characterization of the Hucho taimen transcriptome. Ecol. Evol. 2018, 8, 1271-1285. [CrossRef]

28. Kim, D.; Paggi, J.M.; Park, C.; Bennett, C.; Salzberg, S.L. Graph-based genome alignment and genotyping with HISAT2 and HISAT-genotype. Nat. Biotechnol. 2019, 37, 907-915. [CrossRef] 
29. Simão, F.A.; Waterhouse, R.M.; Ioannidis, P.; Kriventseva, E.V.; Zdobnov, E.M. Busco: Assessing genome assembly and annotation completeness with single-copy orthologs. Bioinform. 2015, 31, 3210-3212. [CrossRef]

30. Camacho, C.; Coulouris, G.; Avagyan, V.; Ma, N.; Papadopoulos, J.; Bealer, K.; Madden, T.L. BLAST+: Architecture and applications. BMC Bioinform. 2009, 10, 421. [CrossRef]

31. Jones, P.; Binns, D.; Chang, H.Y.; Fraser, M.; Li, W.; McAnulla, C.; Pesseat, S. InterProScan 5: Genome-scale protein function classification. Bioinformatics 2014, 30, 1236-1240. [CrossRef]

32. Huerta-Cepas, J.; Szklarczyk, D.; Heller, D.; Hernández-Plaza, A.; Forslund, S.K.; Cook, H.; Von Mering, C. eggNOG 5.0: A hierarchical, functionally and phylogenetically annotated orthology resource based on 5090 organisms and 2502 viruses. Nucleic Acids Res. 2019, 47, D309-D314. [CrossRef] [PubMed]

33. Kanehisa, M.; Sato, Y.; Morishima, K. BlastKOALA and GhostKOALA: KEGG tools for functional characterization of genome and metagenome sequences. J. Mol. Biol. 2016, 428, 726-731. [CrossRef] [PubMed]

34. Savojardo, C.; Martelli, P.L.; Fariselli, P.; Profiti, G.; Casadio, R. BUSCA: An integrative web server to predict subcellular localization of proteins. Nucleic Acids Res. 2018, 46, W459-W466. [CrossRef] [PubMed]

35. Conesa, A.; Götz, S.; García-Gómez, J.M.; Terol, J.; Talón, M.; Robles, M. Blast2GO: A universal tool for annotation, visualization and analysis in functional genomics research. Bioinformatics 2005, 21, 3674-3676. [CrossRef]

36. Kellmann, R.; Mihali, T.K.; Jeon, Y.J.; Pickford, R.; Pomati, F.; Neilan, B.A. Biosynthetic intermediate analysis and functional homology reveal a saxitoxin gene cluster in cyanobacteria. Appl. Environ. Microbiol. 2008, 74, 4044-4053. [CrossRef]

37. Galachyants, Y.P.; Zakharova, Y.R.; Volokitina, N.A.; Morozov, A.A.; Likhoshway, Y.V.; Grachev, M.A. De novo transcriptome assembly and analysis of the freshwater araphid diatom Fragilaria radians, Lake Baikal. Sci. Data 2019, 6, 1-11. [CrossRef]

38. Aranda, M.; Li, Y.; Liew, Y.J.; Baumgarten, S.; Simakov, O.; Wilson, M.C.; Piel, J.; Ashoor, H.; Bougouffa, S.; Bajic, V.B.; et al. Genomes of coral dinoflagellate symbionts highlight evolutionary adaptations conducive to a symbiotic lifestyle. Sci. Rep. 2016, 6, 1-15. [CrossRef]

39. Lin, S.; Cheng, S.; Song, B.; Zhong, X.; Lin, X.; Li, W.; Cai, M. The Symbiodinium kawagutii genome illuminates dinoflagellate gene expression and coral symbiosis. Science 2015, 350, 691-694. [CrossRef]

40. Shoguchi, E.; Beedessee, G.; Tada, I.; Hisata, K.; Kawashima, T.; Takeuchi, T.; Arakaki, N.; Fujie, M.; Koyanagi, R.; Roy, M.C. Two divergent Symbiodinium genomes reveal conservation of a gene cluster for sunscreen biosynthesis and recently lost genes. $B M C$ Genom. 2018, 19, 458. [CrossRef]

41. Cooper, J.T.; Sinclair, G.A.; Wawrik, B. Transcriptome analysis of Scrippsiella trochoidea CCMP 3099 reveals physiological changes related to nitrate depletion. Front. Microbiol. 2016, 7, 639. [CrossRef] [PubMed]

42. Jang, S.H.; Jeong, H.J.; Chon, J.K. De novo transcriptome of the newly described phototrophic dinoflagellate Yihiella yeosuensis: Comparison between vegetative cells and cysts. Mar. Biol. 2019, 166, 104. [CrossRef]

43. Lauritano, C.; De Luca, D.; Ferrarini, A.; Avanzato, C.; Minio, A.; Esposito, F.; Ianora, A. De novo transcriptome of the cosmopolitan dinoflagellate Amphidinium carterae to identify enzymes with biotechnological potential. Sci. Rep. 2017, 7, 11701. [CrossRef]

44. Shi, X.; Lin, X.; Li, L.; Li, M.; Palenik, B.; Lin, S. Transcriptomic and microRNAomic profiling reveals multi-faceted mechanisms to cope with phosphate stress in a dinoflagellate. ISME J. 2017, 11, 2209-2218. [CrossRef]

45. Van Dolah, F.M.; Morey, J.S.; Milne, S.; Ung, A.; Anderson, P.E.; Chinain, M. Transcriptomic analysis of polyketide synthases in a highly ciguatoxic dinoflagellate, Gambierdiscus polynesiensis and low toxicity Gambierdiscus pacificus, from French Polynesia. PLoS ONE 2020, 15, e0231400. [CrossRef]

46. Chen, X.; Schreiber, K.; Appel, J.; Makowka, A.; Fähnrich, B.; Roettger, M.; Gutekunst, K. The Entner-Doudoroff pathway is an overlooked glycolytic route in cyanobacteria and plants. Proc. Natl. Acad. Sci. USA 2016, 113, 5441-5446. [CrossRef]

47. Hildebrand, M.; Abbriano, R.M.; Polle, J.E.; Traller, J.C.; Trentacoste, E.M.; Smith, S.R.; Davis, A.K. Metabolic and cellular organization in evolutionarily diverse microalgae as related to biofuels production. Curr. Opin. Chem. Biol. 2013, 17, 506-514. [CrossRef] [PubMed]

48. Smith, S.R.; Abbriano, R.M.; Hildebrand, M. Comparative analysis of diatom genomes reveals substantial differences in the organization of carbon partitioning pathways. Algal Res. 2012, 1, 2-16. [CrossRef]

49. Obata, T.; Fernie, A.R.; Nunes-Nesi, A. The central carbon and energy metabolism of marine diatoms. Metabolites 2013, 3, 325-346. [CrossRef] [PubMed]

50. Andersson, I.; Backlund, A. Structure and function of Rubisco. Plant. Physiol. Biochem. 2008, 46, 275-291. [CrossRef]

51. Armbrust, E.V.; Berges, J.A.; Bowler, C.; Green, B.R.; Martinez, D.; Putnam, N.H.; Brzezinski, M.A. The genome of the diatom Thalassiosira pseudonana: Ecology, evolution, and metabolism. Science 2004, 306, 79-86. [CrossRef] [PubMed]

52. Derelle, E.; Ferraz, C.; Rombauts, S.; Rouzé, P.; Worden, A.Z.; Robbens, S.; Saeys, Y. Genome analysis of the smallest free-living eukaryote Ostreococcus tauri unveils many unique features. Proc. Natl. Acad. Sci. USA 2006, 103, 11647-11652. [CrossRef]

53. Kroth, P.G.; Chiovitti, A.; Gruber, A.; Martin-Jezequel, V.; Mock, T.; Parker, M.S.; Maheswari, U. A model for carbohydrate metabolism in the diatom Phaeodactylum tricornutum deduced from comparative whole genome analysis. PLoS ONE 2008, 3 , e1426. [CrossRef]

54. Worden, A.Z.; Lee, J.H.; Mock, T.; Rouzé, P.; Simmons, M.P.; Aerts, A.L.; Foulon, E. Green evolution and dynamic adaptations revealed by genomes of the marine picoeukaryotes Micromonas. Science 2009, 324, 268-272. [CrossRef] 
55. Gong, W.; Browne, J.; Hall, N.; Schruth, D.; Paerl, H.; Marchetti, A. Molecular insights into a dinoflagellate bloom. ISME J. 2017, 11,439-452. [CrossRef]

56. Sánchez, B.; Zúñiga, M.; González-Candelas, F.; Clara, G.; Margolles, A. Bacterial and eukaryotic phosphoketolases: Phylogeny, distribution and evolution. J. Mol. Microbiol. Biotechnol. 2010, 18, 37-51. [CrossRef]

57. Fabris, M.; Matthijs, M.; Rombauts, S.; Vyverman, W.; Goossens, A.; Baart, G.J. The metabolic blueprint of Phaeodactylum tricornutum reveals a eukaryotic Entner-Doudoroff glycolytic pathway. Plant. J. 2012, 70, 1004-1014. [CrossRef]

58. Flamholz, A.; Noor, E.; Bar-Even, A.; Liebermeister, W.; Milo, R. Glycolytic strategy as a tradeoff between energy yield and protein cost. Proc. Natl. Acad. Sci. USA 2013, 110, 10039-10044. [CrossRef]

59. Peyraud, R.; Cottret, L.; Marmiesse, L.; Genin, S. Control of primary metabolism by a virulence regulatory network promotes robustness in a plant pathogen. Nat. Commun. 2018, 9, 1-14. [CrossRef] [PubMed]

60. Jyoti, P.; Shree, M.; Joshi, C.; Prakash, T.; Ray, S.K.; Satapathy, S.S.; Masakapalli, S.K. The Entner-Doudoroff and nonoxidative pentose phosphate pathways bypass glycolysis and the oxidative pentose phosphate pathway in Ralstonia solanacearum. MSystems 2020, 5, e00091-20. [CrossRef]

61. Mulholland, M.R.; Morse, R.; Egerton, T.; Bernhardt, P.W.; Filippino, K.C. Blooms of dinoflagellate mixotrophs in a lower Chesapeake Bay tributary: Carbon and nitrogen uptake over diurnal, seasonal, and interannual timescales. Estuaries Coasts 2018, 41, 1744-1765. [CrossRef]

62. Griffin, J.E.; Park, G.; Dam, H.G. Relative importance of nitrogen sources, algal alarm cues and grazer exposure to toxin production of the marine dinoflagellate Alexandrium catenella. Harmful Algae 2019, 84, 181-187. [CrossRef]

63. Chakraborty, S.; Pančić, M.; Andersen, K.H.; Kiørboe, T. The cost of toxin production in phytoplankton: The case of PST producing dinoflagellates. ISME J. 2019, 13, 64-75. [CrossRef] [PubMed]

64. Collos, Y.; Vaquer, A.; Laabir, M.; Abadie, E.; Laugier, T.; Pastoureaud, A.; Souchu, P. Contribution of several nitrogen sources to growth of Alexandrium catenella during blooms in Thau lagoon, southern France. Harmful Algae 2007, 6, 781-789. [CrossRef]

65. Li, T.S.; Yu, R.C.; Zhou, M.J. Short-term effects of different nitrogen substrates on growth and toxin production of dinoflagellate Alexandrium catenella Balech (strain ACDH). Harmful Algae 2011, 12, 46-54. [CrossRef]

66. Jing, X.; Lin, S.; Zhang, H.; Koerting, C.; Yu, Z. Utilization of urea and expression profiles of related genes in the dinoflagellate Prorocentrum donghaiense. PLoS ONE 2017, 12, e0187837. [CrossRef]

67. Pechkovskaya, S.A.; Knyazev, N.A.; Matantseva, O.V.; Emelyanov, A.K.; Telesh, I.V.; Skarlato, S.O.; Filatova, N.A. Dur3 and nrt2 genes in the bloom-forming dinoflagellate Prorocentrum minimum: Transcriptional responses to available nitrogen sources. Chemosphere 2020, 241, 125083. [CrossRef]

68. Bellefeuille, S.D.; Morse, D. The main nitrate transporter of the dinoflagellate Lingulodinium polyedrum is constitutively expressed and not responsible for daily variations in nitrate uptake rates. Harmful Algae 2016, 55, 272-281. [CrossRef]

69. Cuartero, M.; Crespo, G.; Cherubini, T.; Pankratova, N.; Confalonieri, F.; Massa, F.; Bakker, E. In situ detection of macronutrients and chloride in seawater by submersible electrochemical sensors. Anal. Chem. 2018, 90, 4702-4710. [CrossRef]

70. Dagenais-Bellefeuille, S.; Morse, D. Putting the N in dinoflagellates. Front. Microbiol. 2013, 4, 369. [CrossRef]

71. Glibert, P.M.; Wilkerson, F.P.; Dugdale, R.C.; Raven, J.A.; Dupont, C.L.; Leavitt, P.R.; Kana, T.M. Pluses and minuses of ammonium and nitrate uptake and assimilation by phytoplankton and implications for productivity and community composition, with emphasis on nitrogen-enriched conditions. Limnol. Oceanogr. 2016, 61, 165-197. [CrossRef]

72. Allen, A.E.; Dupont, C.L.; Oborník, M.; Horák, A.; Nunes-Nesi, A.; McCrow, J.P.; Bowler, C. Evolution and metabolic significance of the urea cycle in photosynthetic diatoms. Nature 2011, 473, 203-207. [CrossRef]

73. Ou, L.J.; Huang, K.X.; Li, J.J.; Jing, W.Y.; Dong, H.P. Transcriptomic responses of harmful dinoflagellate Prorocentrum donghaiense to nitrogen and light. Mar. Pollut. Bull. 2019, 149, 110617. [CrossRef]

74. Price, D.C.; Farinholt, N.; Gates, C.; Shumaker, A.; Wagner, N.E.; Bienfang, P.; Bhattacharya, D. Analysis of Gambierdiscus transcriptome data supports ancient origins of mixotrophic pathways in dinoflagellates. Environ. Microbiol. 2016, 18, 4501-4510. [CrossRef]

75. Lin, S.J.; Litaker, R.W.; Sunda, W.G. Phosphorus physiological ecology and molecular mechanisms in marine phytoplankton. J. Phycol. 2016, 52, 10-36. [CrossRef]

76. Falhof, J.; Pedersen, J.T.; Fuglsang, A.T.; Palmgren, M. Plasma membrane $\mathrm{H}^{+}$-ATPase regulation in the center of plant physiology. Mol. Plant. 2016, 9, 323-337. [CrossRef]

77. Haley, S.T.; Alexander, H.; Juhl, A.R.; Dyhrman, S.T. Transcriptional response of the harmful raphidophyte Heterosigma akashiwo to nitrate and phosphate stress. Harmful Algae 2017, 68, 258-270. [CrossRef]

78. Hothorn, M.; Neumann, H.; Lenherr, E.D.; Wehner, M.; Rybin, V.; Hassa, P.O.; Ladurner, A.G. Catalytic core of a membraneassociated eukaryotic polyphosphate polymerase. Science 2009, 324, 513-516. [CrossRef]

79. Stüken, A.; Orr, R.J.; Kellmann, R.; Murray, S.A.; Neilan, B.A.; Jakobsen, K.S. Discovery of nuclear-encoded genes for the neurotoxin saxitoxin in dinoflagellates. PLoS ONE 2011, 6, e20096. [CrossRef]

80. Orr, R.J.S.; Stüken, A.; Murray, S.A.; Jakobsen, K.S. Evolution and distribution of saxitoxin biosynthesis in dinoflagellates. Mar. Drugs 2013, 11, 2814-2828. [CrossRef] 
81. Hackett, J.D.; Wisecaver, J.H.; Brosnahan, M.L.; Kulis, D.M.; Anderson, D.M.; Bhattacharya, D.; Erdner, D.L. Evolution of saxitoxin synthesis in cyanobacteria and dinoflagellates. Mol. Biol. Evol. 2013, 30, 70-78. [CrossRef]

82. Zhang, Y.; Zhang, S.F.; Lin, L.; Wang, D.Z. Whole transcriptomic analysis provides insights into molecular mechanisms for toxin biosynthesis in a toxic dinoflagellate Alexandrium catenella (ACHK-T). Toxins 2017, 9, 213. [CrossRef] 